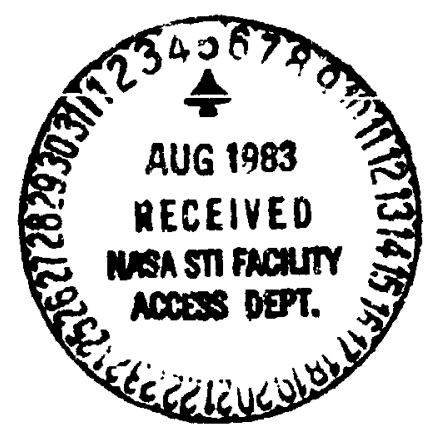

\title{
Parametric Study of Flame Radiation Characteristics of a Tubular-Can Combustor
}

\author{
(NASA-TM-83436) PARAMLTRIC STUDY OF ELAHL \\ RADIATIUN CHARACTETISTICS OF A TUBULAK-CAM \\ CUMBUSTOE (NASA) $13 \mathrm{P}$ IIL AO2/NF AO! \\ Cus. $\angle \mathrm{E}$ Unclas \\ G $3 / 07 \quad 28320$ \\ N $83-29237$
}

Francis M. Humenik, Russell W. Claus,

ansi Geralyn M. Neely

Lewis Resear $-h$ Center

Cleveland, Ohio

Prepared for the

Joint Fo:.. r Generation Conference

sponsored by the American Society of Mechanical Engineers

Indianapolis, Indiana, September 25-29, 1983 
PARAMETRIC STUDY OP FLAME RADIATION CHARACTERISTICS

OF A TUBULAR-CAN COMBUSTOR

\author{
Francis M. Huinemik \\ Russell W. Claus \\ and \\ Geralyn M. Neely \\ Haticnal Aeronautics and Space Administration \\ Lewis Research Center \\ Cleveland, Ohio 44135
}

ABSTRACT

A series of combustor tests were conducted with a tubular-car combustor to study flame radiation characteristics and effects with parametric variations in combustor operating conditions. Two alternate combustor assemblies using a different fuel nozzle were compared. Spectral and total radiation detectors were positioned at three stations along the length of the comoustor can. Data were obtained for a range of pressures from 0.34 to $2.07 \mathrm{MPa}(50$ to $300 \mathrm{psia})$, inlet temperatures from 533 to $700 \mathrm{~K}\left(500\right.$ to $\left.800^{\circ} \mathrm{F}\right)$, for Jet A (13.98 rydrogen) and EZBS (12.38 hydrogen) fuels, and with fuel-air ratios nominally from 0.008 to 0.021 . Spectral radiation data, total radiar.t heat flux data, and liner temperature data are fresented to illustrate the flame radiation characteristics and effects in the primary, secondary, and tertiary combustion zones.

\section{INTRODUCTION}

Recent combustion experiments have emphasized the use of flame radiation measurements to determine effects of fuel quality variations on combustor emissions, flame temperature, and heat transfer characteristics (refs. 1, 2, 3). From analysis of the spectral flame radiance dats, calculations of the flame temperature and soot concentration in each combustion zone yield some explanations for the effects observed (refs. 1, 1, 5). Prom analysis of total radiant heat flux data, some correlations with comburtor liner temperatures have been demonstrated (.ef. 2). Thus, combuntor flame radiation measuremerts provide fundanintal data that can be uned to improve combustor liner thermil analysis and may help establash an analytical heat transfer model. These analytical efforts may yield improved liner durability in future designs by prescribing optimum adjustments to cooling airflow distribution. Also, liner development costs may be reduced by manimizing design iterations.
In order to expand the fundamental flame radistion data base, the series of combustor tests initlated with reference 1 were continued in order to orovide a more complete mapping and parametric investigation of combustor operating variables on flame radiation. Three window-stations and three transducer-stations along the length of the combustor housing assembly provided access for spec$t r a)$ and total radiation sensors respectively. Thus, the flame radiation characteristics and effects in the three combustion zones could be compared.

The primary purpose of this report is to present an overall general description of the variation in spectra: and total flame radietion characteristics in each combustion zone with variations in combustor operating conditions, reduction in fuel hydrogen content, and choice of fuel nozzle.

Data were abtained for a range of pressures from 0.34 to $2.07 \mathrm{MPa} 50$ to $300 \mathrm{psia}$ ), inlet temperatures from $53 ; \mathrm{i} ; 700 \mathrm{~K}\left(500\right.$ to $\left.800^{\circ} \mathrm{F}\right)$ and for Jet $A$ (13.98 hydroyen) and a research test fuel, ERBS (12.98 hydrogen, ref. 6). A single spectral radiance sensing system and three total radiant heat flux transducers provided measurements at the three locations along the length of the combustor can. Dats from these sensors along with selected $i$ ner thermocouple data are presented to illustrate the flame radiation characteristics and effects in the primary, secondary, and tertiary combustion zones.

\section{APPARATUS AND PROCEDURE}

The flame radiation experiments were conducted with a single JTBD. bular can combustor installed in a standard pipe section $125.4 \mathrm{~cm}, 10 \mathrm{inch}$, nominal diameter) modified to be a test housing ausembly as shown in the schematic illustration of figure 1. Combustor inlet instrumentation con- isted of two inlet slatic pressures ard a five point inlet thermocouple rake (Chromel-Alumel) located in the inlet plenum section. The com- 
bustor exit instrumentation (see figure 1) consisted of a set of eight-five point thernocouple rakes (platinu - 13 percent rhodiu/ platinum) for monitoring lhe exit temperature pattern and a set of four gas sample protes for routine exhaust gas analysis. Liner metal tenperatures were measured with 24 thermocouples (Chronel-Alunel) of wich 4 were located on the dowe and the others civided along opposite sides of the combustor can to give 2 separate thermocouples on the outside of sach cooling louver.

The flane radiation instrumentation consisted of three separate radiant heat flux transducers installed for continuous weasurenents at three stations along the combustor housing and aingle spectral raciation detector unit positioned in Iine with one of the three window ports as illustrated in figure 2. The three radiant heat flux transducers were a Gardon-type gauge that senses the radial transfer of heat to a sink by use of a differential thermoelectric circuit. Bach transducer was water-cooled and required a continuous nitrogen purge to sweep the sensor tip. The stem of the transducer extended to the inner surface of the combustor liner through an existing arr entry hole or a specially added clearance hole. The measurement locations nominally corresponded to primary (11), secondary (12), and tertiary (13) combustion zones. Thus, a reading of total radiant heat flux in each combustion zone was obtained with each spectral scan of the flame radiance at a selected window port.

The spectral radiation system components included an optical sensing head unit, progranmable controller, and a printer as shown in figure 3. The sensing head consisted of an optical radiation telescope system, a variable spectral filter system, and an indium antimonide radiation detector which required high pressure gaseous nitrogen for cooling. The programable controller provided - cholce of step-aconning cycle for censing at the desired vave sength increments. Further details and dourription of the apoctral radinector apmaratus are given in reference 1 . The losation of the windor ports for spectral measurements and the location of the three total radiant heat flux transducers are included with the photographs of the JT8D tubular can comburtor in figure 4 . The arrangement of the apparotus in the test facility is shown in the photograph of figure 5 . The exit instrumentation rakes and gas sarple probes are on the left. The flow direction is rlght to left. The epectral viewing ports contained sapphire windows whose transittance bandwidh and high temperature capability are ouited to this application. For safety reasons, $10 \mathrm{cal}$ focusing of the spectral detector optics and optimizing the output signal was conducted only at low presture (0.34 MPa, $50 \mathrm{psia).} \mathrm{Spectral} \mathrm{data} \mathrm{scan-}$ iling and recording was initiated from an adjacent control room.

Two candidate fuel nozzes, FNol and FN\$2, were selected for comparison in this test program. FNtl was a standard type fuel nozzle for a conventional JTBD assembiy configuration: $N \geqslant 2$ was a comercisl substitute offered for experimental comparison. Both fuel nozzles, FN1 and FN"2, were the dual orifice pressure atomizing type. From flow calibrations of each fuel nozzle, FNt 2 produced a higher flow rate than Fill (by about 10-158) at representstive primary and secondary test pressures but no other significant differences were apparent. Testing was initiated with fuel nozzle PNII to obtain a representative set of data; then with fuel nozzle FN12, a more complete data set was obtained which included unsts with both Jet $A$ (13.98 hydrogen) and ERBS (12.93 hydrogen) fuels.

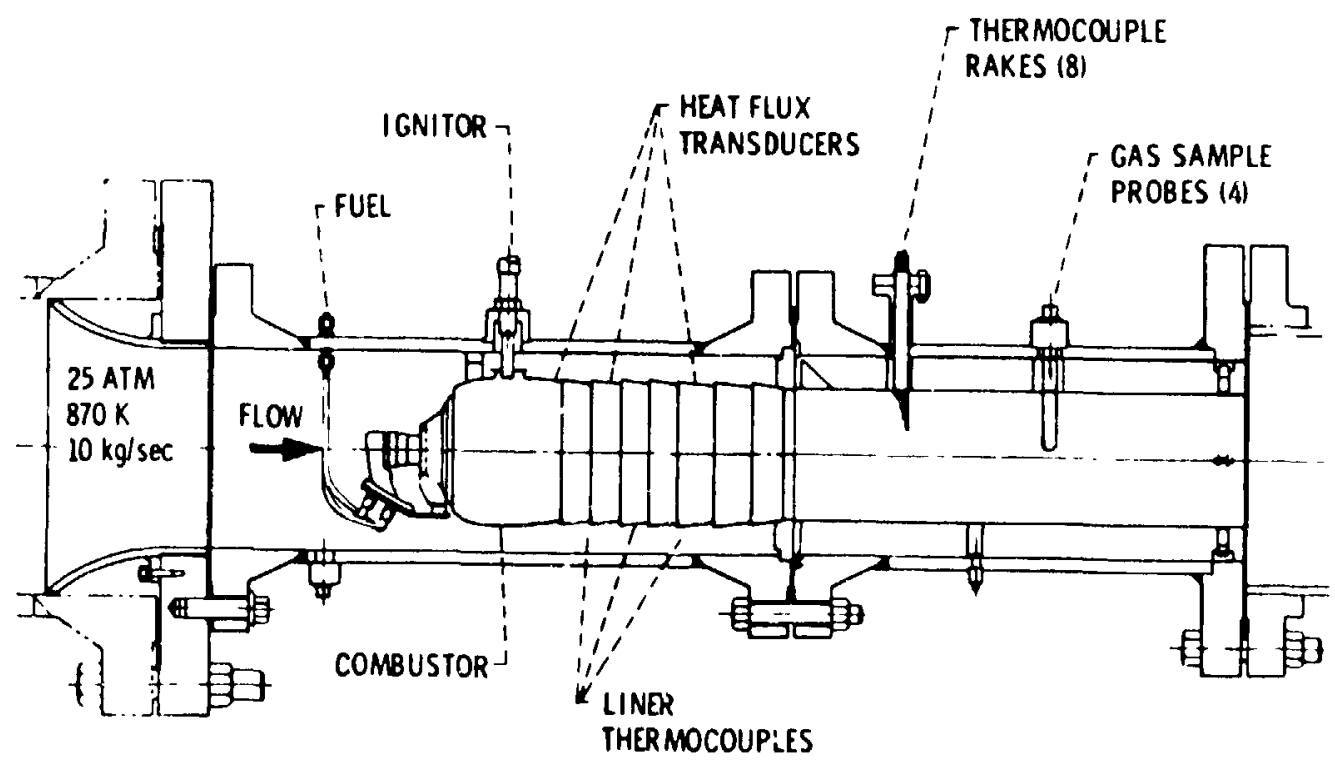

Figure 1. - Schematic of tubular combustor installation. Nominal flow capabilities of test facility: inlet pressure, $25 \mathrm{~atm}$; inlel air temperaturc, $870 \mathrm{~K}$; inlet airflow rate, $10 \mathrm{~kg} / \mathrm{sec}$. 


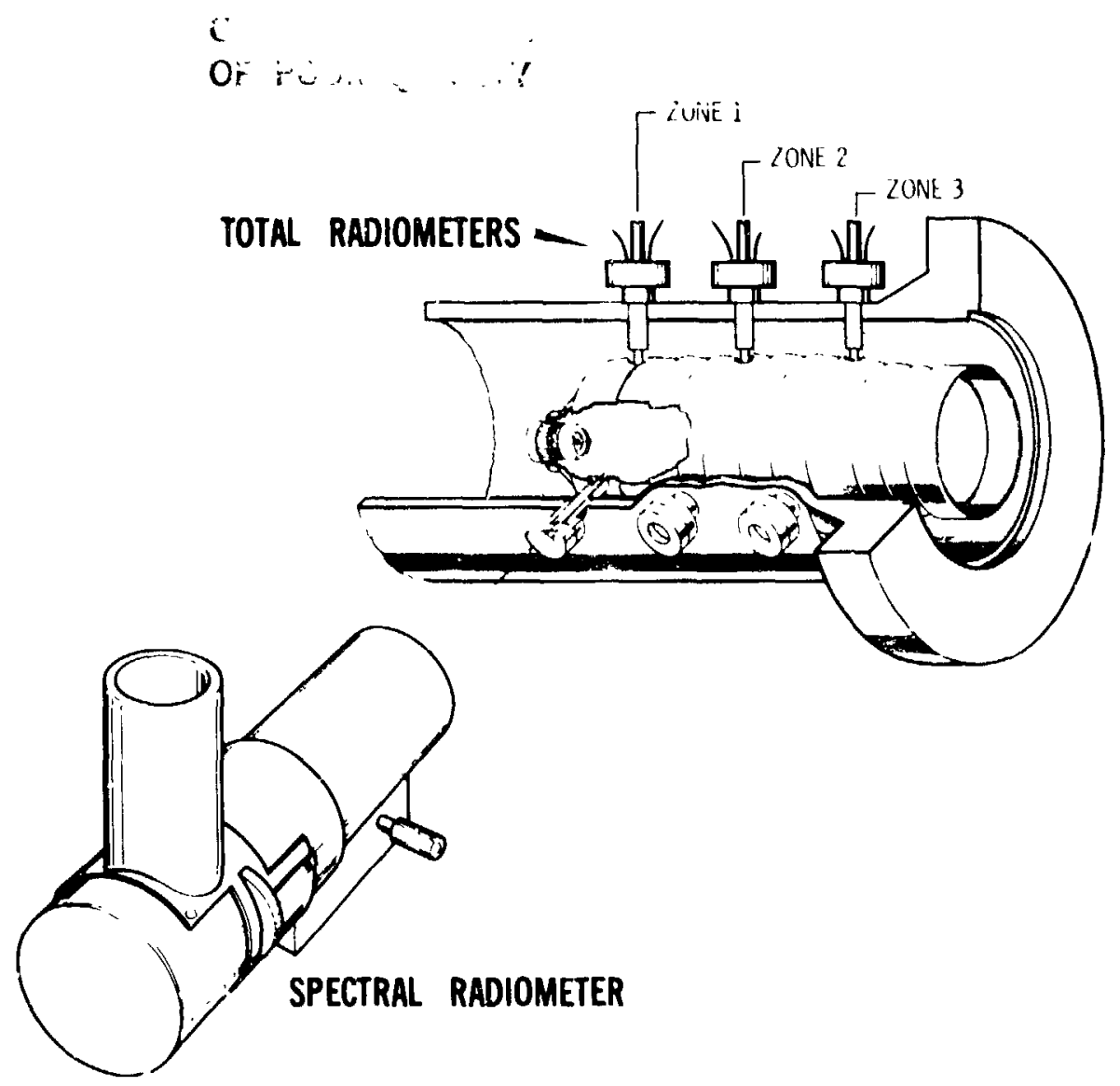

Hegure 2. - Assembly of tubular combustor for flame radiation studies.
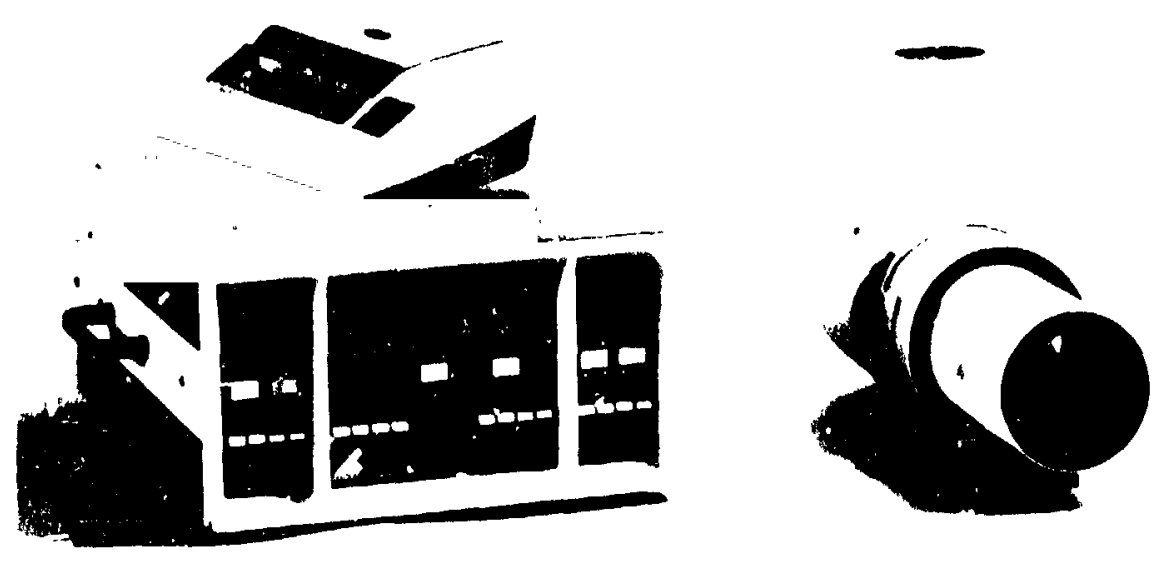

( ) 0537

Fiqure 3. Spectral radionleter system components: programmable controller with printer, and sensing hedd. 
C-83-2084

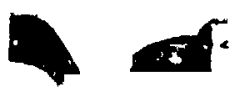

i<smiles>[3H]C=C</smiles>

$\sum_{x=0}^{m+j}$

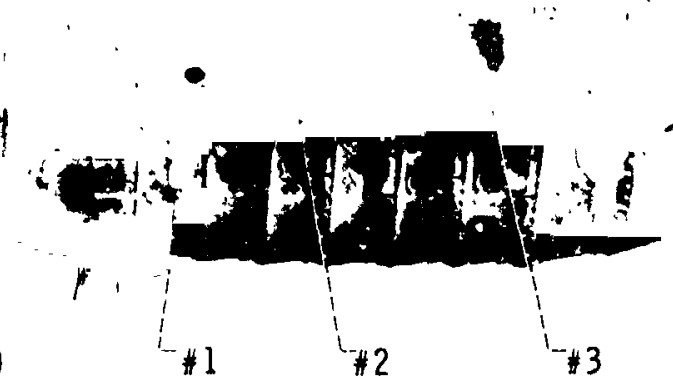

3
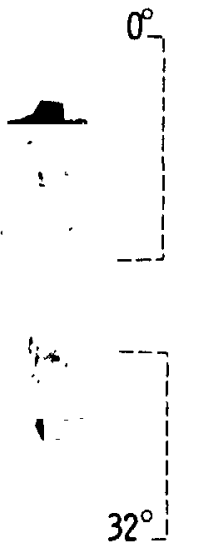

\begin{tabular}{|c|c|c|c|}
\hline \multirow[t]{2}{*}{ ZONE } & \multicolumn{2}{|c|}{$X_{\text {L }}$ LCCATION } & \multirow{2}{*}{$\begin{array}{c}\theta, L O C . \\
\text { deg }\end{array}$} \\
\hline & $\mathrm{cm}$ & in. & \\
\hline 1 & 12.7 & 5.0 & 32 \\
\hline 2 & 18.5 & 7.3 & 0 \\
\hline 3 & 28.7 & 11.3 & 0 \\
\hline
\end{tabular}

SPECTRAL RADIANCE

C-83-2083
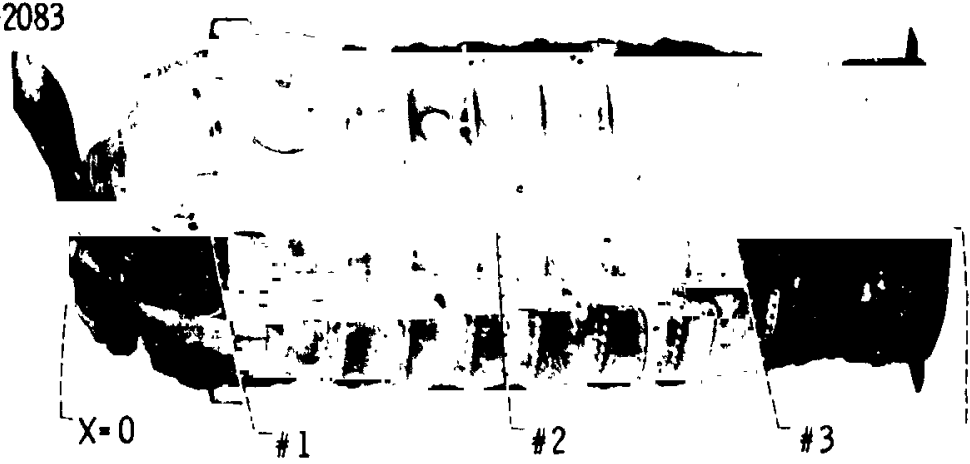

\begin{tabular}{|c|c|c|c|}
\hline \multirow{2}{*}{ ZONE } & \multicolumn{2}{|c|}{$x_{1}$ LOCATION } & \multirow{2}{*}{$\theta_{1}$ LOC. } \\
\cline { 2 - 3 } & cm & in. & deg \\
\hline 1 & 7.4 & 2.9 & 300 \\
2 & 22.1 & 8.7 & 300 \\
3 & 34.0 & 13.4 & 300 \\
\hline
\end{tabular}

Figure 4. - Photographs of tubular-can combustor with flame radiation zone locations.

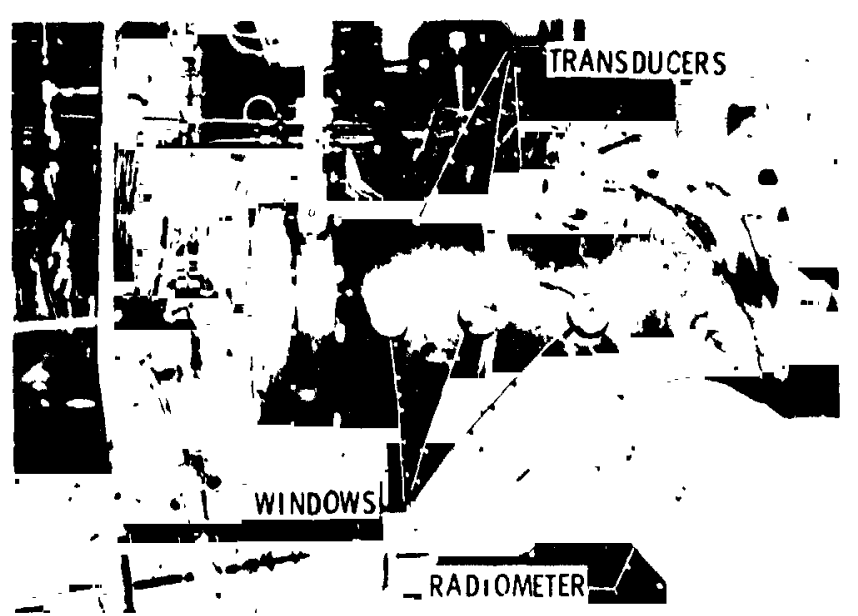

Figure 5. - Photograph of JT8D combustor housing assembly during experiments. Installation of radiant heat flux transducers, location of window-stations and spectral radiometer sensing head are shown. 
Test conditions (see Tabie I) vere selected to cover the normal range of combustor operation while mointaining a constant mass flow parameter

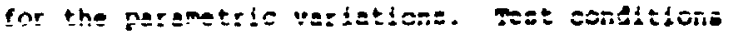
include combustor pressures of $0.34 \mathrm{MPa}$ ( 50 pala). $0.69 \mathrm{MPa}(100 \mathrm{psia}), 1.38 \mathrm{kPa}(200 \mathrm{psia})$, and 2.07 MPa (300 peia), combustor inlet temperatures of $533 \mathrm{~K}\left(500^{\circ} \mathrm{F}\right), 616 \mathrm{~K}\left(650^{\circ} \mathrm{F}\right)$ and $700 \mathrm{~K}\left(800^{\circ} \mathrm{F}\right)$, with fuel-air ratios nominally fron 0.008 to 0.021 .

Teat fuels (see rable II) included the conventional Jet $A$ and the experimental ERas fuel (ref. 6). Many recent combustion experinente have included tests wh ERBS fuel because 1 th 1 s representative of assible future fuel that has potential for use if another fuel crisis occurs or fuel supplies are disrupted. The data obtained with this fuel indicate combustion performance trends with reductions in fuel hydrogen content. Measurement of airflow rates were obtained from a conventional ASME orifice station; mesurement of fuel flow rates were obtained from conventional turbine type flowmeters. The NSA Lewis ESCORT automatic data acquastion system provided on-lane instantaneous monitoring of data with formal data recording and batch processing using the laboratory IBM $370 / 3033$ system.

TABLE 1. - TEST CONDITIONS

\begin{tabular}{|c|c|c|c|c|c|}
\hline \multicolumn{2}{|c|}{$\begin{array}{l}\text { Combustor } \\
\text { pressure }\end{array}$} & \multirow{2}{*}{\multicolumn{2}{|c|}{$\begin{array}{c}\text { Combustor } \\
\text { inlet } \\
\text { temperature }\end{array}$}} & \multicolumn{2}{|c|}{ Airflow rate } \\
\hline & & & & \multirow[t]{2}{*}{$\mathrm{kg} / \mathrm{sec}$} & \multirow[t]{2}{*}{$\mathrm{lb} / \mathrm{sec}$} \\
\hline $\mathrm{MPd}$ & $\beta>1 d$ & $k$ & 'F & & \\
\hline $\begin{array}{r}0.34 \\
.69 \\
1.38 \\
2.07\end{array}$ & $\begin{array}{r}50 \\
100 \\
200 \\
300\end{array}$ & 533 & 500 & $\begin{array}{r}1.69 \\
3.37 \\
6.75 \\
10.12\end{array}$ & $\begin{array}{r}3.72 \\
7.44 \\
14.88 \\
22.32\end{array}$ \\
\hline $\begin{array}{l}0.09 \\
1.39 \\
2.0 i\end{array}$ & $\begin{array}{l}100 \\
200 \\
300\end{array}$ & $\begin{array}{l}616 \\
616 \\
616\end{array}$ & $\begin{array}{l}650 \\
650 \\
650\end{array}$ & $\begin{array}{l}3.14 \\
6.28 \\
9.42\end{array}$ & $\begin{array}{r}6.92 \\
13.84 \\
20.76\end{array}$ \\
\hline $\begin{array}{l}0.69 \\
2.07\end{array}$ & $\begin{array}{l}100 \\
300\end{array}$ & $\begin{array}{l}700 \\
700\end{array}$ & $\begin{array}{l}800 \\
800\end{array}$ & $\begin{array}{l}2.95 \\
8.84\end{array}$ & $\begin{array}{r}6.50 \\
19.50\end{array}$ \\
\hline
\end{tabular}

TABLE 11. - FUEL CHARACTERISTICS

\begin{tabular}{|c|c|c|}
\hline Specifications & Jet-A & ERBS \\
\hline $\begin{array}{l}\text { ASTM distillation, } K \text { : } \\
\text { Initial boiling point } \\
10 \text { percent evaporated } \\
50 \text { pnrrent evaporated } \\
90 \text { percent evaporated } \\
\text { Find boiling point }\end{array}$ & $\begin{array}{l}411 \\
451 \\
479 \\
517 \\
531\end{array}$ & $\begin{array}{l}435 \\
461 \\
488 \\
552 \\
601\end{array}$ \\
\hline Specific gravity at $289 k$ & 0.8142 & 0.8381 \\
\hline Freezing point, $k$ & 226 & 244 \\
\hline viscosity at $250 \mathrm{~K}, \mathrm{~m}^{2} / \mathrm{sec}$ & $5 \times 10^{-6}$ & $7.2 \times 10^{-6}$ \\
\hline Net heat of combustion, $\mathrm{J} / \mathrm{g}$ & 43304 & 42200 \\
\hline Hydrogen, Dercent by we ight & 13.9 & 12.9 \\
\hline Aromatics, percent by volume & 17.2 & 28.8 \\
\hline Sulfur (total), percent by weight & 0.020 & 0.065 \\
\hline
\end{tabular}

RESULTS AND DISCUSSION

Fundamental flame radiation data were obtained with an experimental tubular can combustor configuration to determine variations in flame radiance characteristics for a range of parametric test conditions. Data are presented in figures 6 to 9 to illustrate some fundamental flame radiation characteristics wich are ureful for comparIng porformance trends, examining correlations, and explaining variatione in each combustion sone. specific results discussed are a follows:

1) comparison of two candidate fuel nozzles, Itgure 6 7

2) spectral flame radiance variation, figure

3) total radiunt heat flux variation, figure 8;

1) comparison of radiant heat flux with liner temperature, figure 9 .

\section{Comparison of Puel Nozzles}

The variations in radiant heat flux distribution with variations in fuel-air ratio produced by fuel nozzles FN\$1 and FNA 2 with Jet $A$ fuel are shown in flgure 6 . These data are grouped to compare the results in each combustor zone at the low combustor pressure of $0.69 \mathrm{MPa}$ (100 psia) with the high combustor pressure of $2.07 \mathrm{MPa} 1300$ paia). In general, significantly different rates of radiant heat flux variation are apparent in each zone along with an overall increase in radiant heat flux levels with combustor pressure increase.

The specific characteristics for combustion zone 11 (primary, see figure $6(a)$ and (b) only) show that FN 2 produced higher radiant heat flux than FNI l at both the low ald high combustor presaure levels for fuel-air ratios from 0.012 and greater. Since soot is a major contributor to total flame radiation, increased levels of radiant heat flux are usually an indicator of higher soot concentrations. However, other data (higher 'ocal Iiner temperatures and higher exhaust $\mathrm{HO}_{\mathrm{x}}$ levels) Indicate that primary rone flame temperatures may also have been higher with EN/2. For instance, at the 10w pressure condition with $f / a=0.018$, local liner temperatures were $50 \mathrm{~K}\left(89^{\circ} \mathrm{F}\right)$ higher in this sone with FNi2 whereas at the high pressure condition with $t / a=0.016$, local liner temperatures were $34 \mathrm{~K}\left(60^{\circ} \mathrm{P}\right) \mathrm{higher}$ with FNi2. Similarly, exhaust $\mathrm{NO}_{\mathrm{x}}$ levels were 12 ppm higher $(82$ Ppm va $94 \mathrm{ppm}$ ) at the low pressure condition (f/a - 0.018) with FN 2 and 45 ppm higher (86 ppm vo $131 \mathrm{ppm})$ at the $h i g h$ pressure condition (f/a = $0.016)$ with FN 2 . These data are indicators that FN 2 produced higher flame temperatures resulting in substantially increased $\mathrm{NO}_{x}$ levels and higher local liner temperaturea. Thus, combination of higher flame temperetures and increased soot concentration may have produced the higher radiant heat flux in this zone with FN 2 .

The characteristics in combustion zone (sewondary, see figure 6 (c) and (d) only) show rapidly changing combustion reaction condltions occurring 'n this zone with increase in fuel-air ratio. With FNI2, there was a very steek Increase in radiant heat flux at the high combustor preswre condition ranging from $16 \mathrm{w} / \mathrm{cm}^{2}$ (f/a = $0.0089)$ to a peak of $80 \mathrm{~W} / \mathrm{cm}^{2}$ (f/a $\left.=0.0159\right)$ with FN1, the peak radiant heat flux level was 77 $\mathrm{h} / \mathrm{cm}^{2}(\mathrm{f} / \mathrm{a}-0.0130)$. Thus, at the high pres- 
sure condition, relatively high radiant heat flux levels are evident in the secondary zone with either fuel nozzle.

The characteristics in combustion zone 13 (tertiary, see figure 6 (e) and (f) only), show

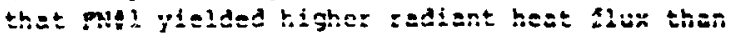
FN 2 at both low and high combustor pressure levels. In this zone, combustor temperatures have been reduced, combustion reactions are completed, and therefore, the radiant heat flux levels are attributed solely to soot concentration. Thus, with the substantial difference in radiant heat flux levels between the two fuel nozzles, it is evident that FNil results in higher exhaust amoke levels than FN 2 . Since FN\$2 produced much higher exhaust $\mathrm{NO}_{x}$ leveli3, a tradeoff between exhaust smoke and exhaust NO, was obtained by the choice of fuel nozzle alone.

In summary, the substitute experimental fuel nozzle, FN 2, produced a significant re-distribution of total radiant heat flux between combustion zones. It is also apparent that radiant heat flux levels in ach cone increased with increase in combustor pressure. Finally, the combustor assembly with FN12 produced less exhaust Bmoke than FNIl, but higher exhaust NO ${ }_{x}$ levels. The corbustor assembly with FN/2 was utilized for all subsequent testing.

Spectral Flame Radiance Variation

The variations in spectral flane radiance for nominal fuel/air ratios of 0.016 obtained with fuel nozzle FNi2, and with Jet $A$ and ERBS fuels are shown in figure 7 . Data at 0.34 MPa ( 50 psia) and $0.69 \mathrm{MPa}(100 \mathrm{pria}$ ) are prese 'ed in order to focus on the comparison of differences between the two fuels. Data at higher pressures up to 2."7 MPa ( 300 psia) were also obtained but did not reveal any significant fuel differences.

In combustion zone 1 (primary, see fig. 7 (a) and (b)), spectral flame radiance levels at a nominal reference wavelength near $1.5 \mathrm{\mu m}$ and combustor pressure of $0.34 \mathrm{MPa}(50$ psia) was about $1.3 \mathrm{~W} /\left(\mathrm{cm}^{2} \mathrm{st} \mathrm{jm}\right)$ with Jet $\mathrm{A}$ fuel and increased to about $2.7 \mathrm{~W} /\left(\mathrm{cm}^{2} \mathrm{sI} \mathrm{\nu m}\right)$ with ERBS fuel. With combustor pressure of $0.69 \mathrm{MPa}$ (100 psia), spectral flame radiance levels increased substantially to $1.2 \mathrm{~W} /\left(\mathrm{cm}^{2} \mathrm{Br}, \mathrm{m}\right)$ with Jet $A$ fuel and to 4.5 $w /\left(\mathrm{cm}^{2} \mathrm{gr}, \mathrm{m}\right)$ with ERBS fuel. The peaks at about $4.5 \mu \mathrm{m}$ wavelength are due to $\mathrm{CO}_{2}$ band radiance and ate an indicator of flame temperature (ref. 1). Comparing the peaks indicates only slightly teduced flame temperature with combustor pressure Increase but substantial flame radiance increase which is thus attributed ts suhstuntial increase in soot concentration. The increase in flame radiance with ERBS fuel $(12.9$ hydrogenl was most eviac... it the low combustor preasure and tends to be less distinct at high combustor pressures.

In combustion zone 12 (secondary, see figure 7 (c) and (d)), spectral flame radiance levels at $1.5 \mathrm{Lm}$ wavelength and combustor pressure of 0.31 MPa (50 psia) was about $1.2 \mathrm{~W} /\left(\mathrm{cm}^{2}\right.$ ar $\mu$ m) with Jet $A$ fuel and ancreased to about $2.4 \mathrm{~W} / \mathrm{cm}^{2}$ or $\mu \mathrm{m})$ with r.RBS fuel. With combuator preseure of $0.69 \mathrm{MPa}(100 \mathrm{psia}$ ), epectral flame radiance levels increased substantially to about 5.7 $w^{\prime}\left(\mathrm{cm}^{2}\right.$ ar $\left.11 \mathrm{~m}\right)$ with both Jet $A$ and ERBS fuels. Thie similarity in $\mathrm{CO}_{2}$ band radiance peaks at 4.5 hm wavelength indicates very little difference in flame temperature at both combustor pressures and with either fuel. Thus, only amall increase in soot concentration was evid.st at the lower combustor pressure with the ERBS fuel. The peaks at $2.7 \mathrm{um}$ wavelength are the contribus. in to the flame radiance due to water vapor which $z$ re most aident at ion conituatio pleasures.

In combustion zone 3 (tertiary, see figure 7 (e, and (f)), epectial flame radiance levels were yenerally below $0.6 \mathrm{~W} /\left(\mathrm{cm}^{2}\right.$ ar $\left.\mu \mathrm{m}\right)$ with both combustor pressures and with both fuels. The $\mathrm{CO}_{2}$ band radiance peaks are very similar and indicate the lowering of combustor temperature in this zone. It thus appears that soot concentration levels are practically identical with either fuel and greatly reduced compared to zones 11 and 12 . Thus, despite higher soot levels produced in the primary zone $w$ ith ERBs fuel, the additional coot was burned up before it reached the combustor exit. This indicates that with either fuel there was no discernible difference in exhaust smoke levels.

\section{Total Radiant Heat Flux Variation}

The variations in total radiant heat flux with increase in combustor pressure for each combustion zone are shown in figure 8 . These data were obtained with FN12 for a nominal fuel-air ratio of 0.016 , inlet temperatures of $533 \mathrm{~K}\left(500^{\circ} \mathrm{F}\right)$ and $615 \mathrm{R}\left(650^{\circ} \mathrm{F}\right)$, with Jet $A$ and ERBS fuels. There is a fast rate of increase in radiant heat flux in combustion zones 1 and 12 at the low combustor pressure levels and a slow rate of increase in radiant heat flux at the high combustor pressure levels. This generally corresponds to the expected increase in flame emissivity with increase in combustor pressure. Combustor zones 11 (primary) and 2 (secondary) produced very similar levels of radiant heat flux ranging from about $16 \mathrm{w} / \mathrm{cm}^{2}$ at low combustor pressures to about $78 \mathrm{~W} / \mathrm{cm}^{2}$ at a combustor pressure of $2.07 \mathrm{MPa}(300 \mathrm{psia})$ with Jet A fuel (see figure $8(a)$ ); whereas, combustor zone 13 (tertiary) was much lower and ranged only from about 7 to $29 \mathrm{~W} / \mathrm{cm}^{2}$ for this range of test conditions. There was a small increase of up to 10 $W / \mathrm{cs}^{2}$ in radiant heat flux intensity in each zone with ERBS fuel compared to Jet $A$ fuel. The effect of increasing the r,ombustor inlet teinperature by $B 2 \mathrm{~K}\left(1 ; 0^{\circ} \mathrm{F}\right)$ dic not produce a notabie varlation in the intensity of the radiant heat flux (see figure 8 (a) and (b)).

\section{Comparison of Radiant lleat Flux with Lirier}

\section{Temperatures}

The total radiant heat flux data in each combustion zone for two combustor pressures of 0.69 MPa (100 psia) and $2.07 \mathrm{MPa}(300 \mathrm{fsid})$; nominal fel-air ratio of 0.016 ; for jet $A$ and ERBS fuels are how in figure 9 (a) for on inlet temperature of $533 \mathrm{~K}\left(500^{\circ} \mathrm{F}\right)$ and in figure $9(\mathrm{~b})$ for an inlet temperature of $700 \mathrm{~K}\left(800^{\circ} \mathrm{F}\right)$. The corresponding local liner temperature data are shown in figure 9 (c) and (d) respectively. These data lllustrate that although the radiant heat flux increased as expected with combustor pressure increase, the Iiner temperatures for a combustor pressure of $2.07 \mathrm{MPa}(300 \mathrm{psia})$ were cubstantially lower than those for a combustor pressure of $0.69 \mathrm{MPa} 1100$ paia). This is attributed to a large increase in convective cooling at $h i g h$ piessures sufficient to of fet the increased flame rariation and still reduce liner temperatures. There also was an increase in radiant heat flux and liner temperatures 
with the increase in combustor inlet temperature trom 533R $\left(500^{\circ} \mathrm{F}\right)$ to $700 \mathrm{~K}\left(800^{\circ} \mathrm{F}\right)$. This is an indicator that flame temperatures increased proportlonately and that the fllm cooling effectlvenose is also reduced with the higher inist temperature condition. The ERBS fuel data consistently indicated an additional increase in radiant hest flux and liner temperatures in each conbustion zone coapared to the Jet $A$ fuel data. A large increase of $33 \pi\left(59^{\circ} \mathrm{P}\right)$ in local liner temperature with the ERas fuel was upecially evident in combustion zone $\$ 2$ with combustor pressure of 0.69 MPa (100 psia) and combustor inlet temperature of $533 \pi\left(500^{\circ} \mathrm{F}\right)$. The highest radiant heat flux occurred in combustion zone 1 (primary) with combustor pressure of $2.07 \mathrm{MPa}(300 \mathrm{paia})$ and combustor inlet temperature of $700 \mathrm{x}(800 \%)$, wereas, the highest differential iner tamperatures also occurred in combustion zone 11 but at the lower combustor pressure of $0.69 \mathrm{MPa}(100$ psia) with combustor inlet temperature of $700 \mathrm{R}$ $\left(800^{\circ} \mathrm{F}\right)$.

SUMMARY OF RESULTS

Spetral flame radiance characteristics and total radiant heat flux measurements were obtained with a tubular can combustor for a range of pressures from 0.34 to 2.07 MPa (50 to 300 psia). inlet air temperatures from 533 to $700 \mathrm{R}$ ( 500 to $\left.800^{\circ} \mathrm{F}\right)$, and for Jet $A$ and ERBS $(12.98$ hydrc, $\in \mathrm{n})$ fuels.

A comparison of two fuel nozzles over ange of fuel-air ratios from 0.0087 to $0.0212 \mathrm{was} 11-$ lustrated with Jet a fuel. A substitute experimental fuel nozzle produced a re-distribution of total radiant heat flux between combustion zones, substantially higher total radiant heat flux levels in the primary zone, a seep increase in secondary zone heat flux from $16 \mathrm{w} / \mathrm{cm}^{2}$ (f/a, 0.0039 ) to a peak of $80 \mathrm{~W} / \mathrm{cm}^{2}$ (f/a, 0.0159) with a combustor pressure of $2.07 \mathrm{MPa}(300 \mathrm{psia})$, and lower total radiant heat flux levels in the tertiary zone.

The other aignificant flame radiation characteristics and effecto for the tubular-can combustnc with the substitute fuel nozzle are as follows:

1. For a tuel-air ratio of 0.016 , and inlet air temperature of $533 \mathrm{~K}\left(500^{\circ} \mathrm{F}\right)$, the apectral flame radiance (nominal wavelength near $1.5 \mathrm{\mu m}$ ) substantially increased from level of about 1.3 to 1.2 $\omega /\left(\mathrm{cm}^{2}\right.$ or $\left.\mu \mathrm{m}\right)$ in the primary zone, from 1.2 to $5.7 \mathrm{w} /\left(\mathrm{cm}^{2} \mathrm{si} \mu \mathrm{m}\right)$ in the eecondary zune, and from 0.15 to $0.6 \mathrm{~W} /\left(\mathrm{cm}^{2}\right.$ $\forall \mathrm{r} \mu \mathrm{m})$ in the tertiary zone with a combustor pressure increase from 0.34 MPa (50 psia) to $0.69 \mathrm{mpa}(100$ pila) using Jet. A fuel.

2. For a fuel-air ratlo of 0.016 , and inlet - ir temperature of $533 \mathrm{~K}\left(500^{\circ} \mathrm{T}\right)$, the total radiant heat flux oubutantielly increased from level of about 16 $W / \mathrm{cm}^{2}$ to $66 \mathrm{~W} / \mathrm{cm}^{2}$ in the primary sone, from 16 to $78 \mathrm{~W} / \mathrm{cm}^{2}$ in the secondary zone, and from 7 to $29 \mathrm{~W} / \mathrm{ca}^{2}$ in the tertlary zone with a combustor pressure increase trom $0.34 \mathrm{MPa}(50 \mathrm{ps}$ la) to 2.07 MPa (300 psia) using Jet $A$ fuel.
3. A comparison of total radiant rait flus variation and differential lowa i iner temperature variation by combisticn zone for c fuel-air ratio of 0.016 revaled that with conbustor inlet aif sempera ture of $700 \times\left(800^{\circ}\right)$, the hlghest radiant heat flux occure ir the primary zone with a combustor preasure of 2.07 MPa (300 pile), whereas, the highest difterential liner ceaperitures occur with a combustor presure of $0.69 \mathrm{MPa}$ (100 peia), and also in the primary zone.

4. There was an increase in local liner temperatures with ERBS fuel wich ranged up to $33 \mathrm{~K}\left(59^{\circ} \mathrm{F}\right)$ higher than those obtained with Jet $A$ fuel in combustion zone 12 at low power conditions of 0.69 upa (100 psia), 533R (500\%F), f/a 0.016 .

\section{C.SACLUDING REMARKS}

Flame radiation data are a necessary input to the fundamental data base required for advanced liner thermal analysis and to establioh an analytical heat transfer nodel. The data which have been presented lndicate the general flame radiation characteristics and effects produced with varletions in operating conditions and choice of fuel nuzzle. More detailed heat transfer analynis and other auxiliary calculations using the sita from thil test program are continuing and underjoing evaluation. The preliminary interpretaticns of this data are based on the previous experiments which are referenced as applied to this data aet.

\section{ACKNOWLEDGENENTS}

This serdes of tubular-ian combustor tests r*quized the support of several individuals and organivational elements at the NASP Lewis Research Center. The author wish to express their oppreciation to the following groups and individuals: Computer Services Division: Test Installations Diviaion; and, In particular, Robert C. Ehlers, Thomas F. Nierzoda, and Oavaldo Rivera, members of the Research Experiments Branci; who were responsible for test operations.

\section{RETERENCES}

1. Claus, Ruaseld W.: Spectrs. Mlaks Radiance from a Tubular-Can Combulto. WHSA TP-1722, 1981 .

2. Ruznar, R. J, Tober:, $r$,., and Cohn, A.: Combustor Flame Radiation and Wall Temperatures for 2 Distillate and a Coal Derived Liquid Fuel. ASME Puper No. 82-GT-208.

3. Najfer, Y. S. Y, , snd Goodger, E. M.: Radiation and snoke from tr: Gar Turbine Combustor using heavy Fuela. ASME paper No. 81-HT-21.

4. Norgren, Car 1. T. : Determination of Primaryzone smoke Concentrations from Spectral Radience rasurements in Gas Turbine Combistors. MASA TW D-6410, 1971 . 
5. Norgren, Carl T., and Ingebo, Robert D.: Spectral Radiance masuramente end $\mathrm{Ce}$ 'sulated soot concentration Along the Langth of en Experimental Conbutor. MASa IM $x-3994,1910$.

6. Seng, Gary T.: Characterisation of an bxperimental Rofícee Broadened-Specification (ERBS) Aviation Tirbina Fuel and BRBs Fuel Blenda. MASA IM-02863, Auguat 1982.

VIN: … PAGE IS OF PCü guritity
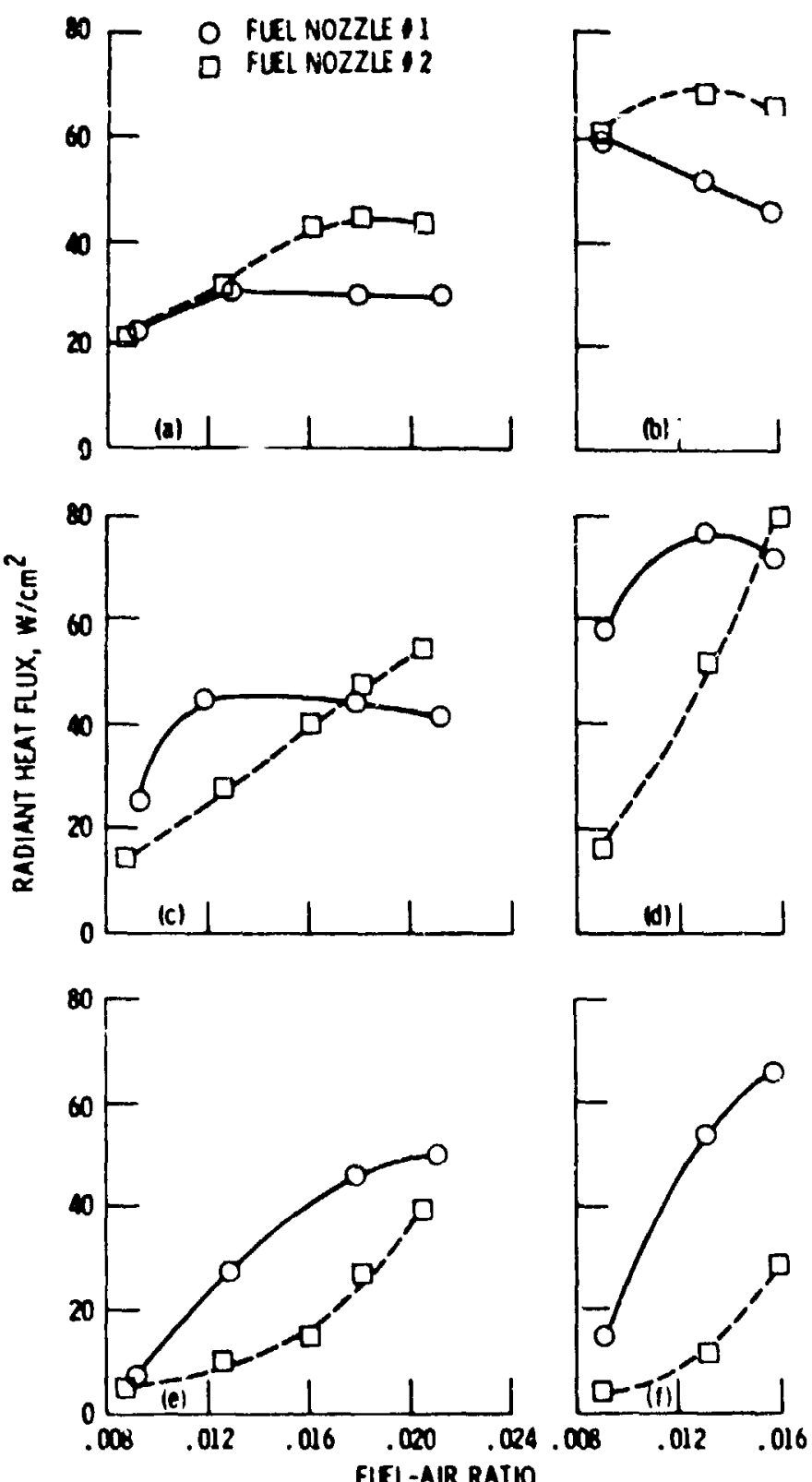

(a) Zone 11 (primary): combustor pressure, a.69 MPa 1100 pial.

(b) Zone 1 (primaryl: combustor pressure, $207 \mathrm{MPa}: 00$ psia).

(c) Zone 12 (secontary); combuslor pressure, 0.69 MPa (100 psia).

(d) Zone 2 (secondary); combustor pressure, $207 \mathrm{MPa}$ (300 psia).

(e) Zone 3 mertiaryl; combustor pressure, Q.69 MPa 1100 ps(a).

(f) Zone 13 Mertiaryl; combustor pressure, 2 or MPa $(300$ psia).

Higure 6. - Comparison of standard (AN-1) and substitule $(\mathbb{A N}-2)$ fuel nozzles: variation in total radiant heat flux with variation in luel-air ratio; Jel A fuel: inlet air temperature, $533 \mathrm{~K}\left(500^{\circ} \mathrm{Fl}\right.$. 


\section{y.}

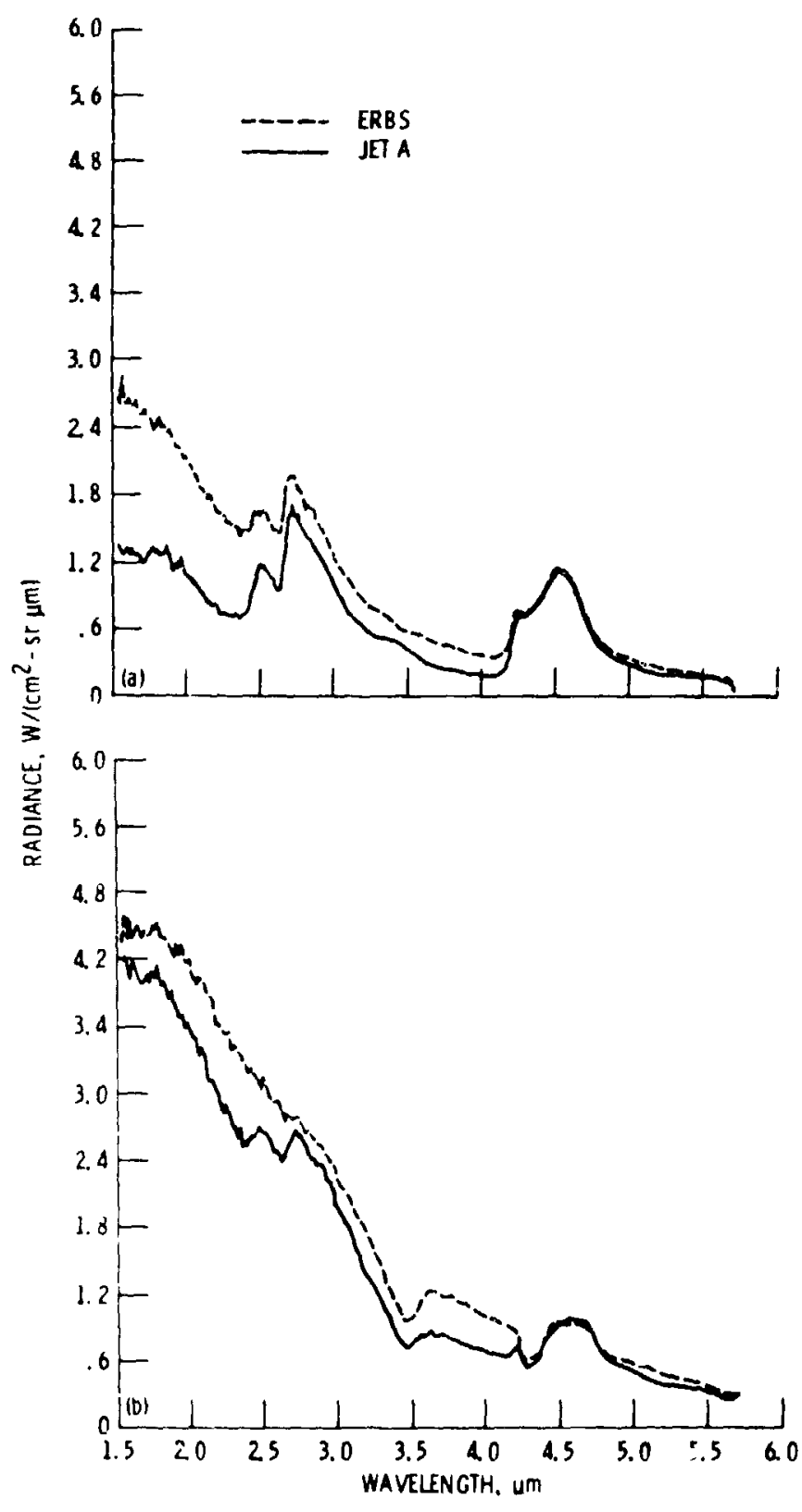

(a) Zone 11 (primary); combustor pressure, $0.34 \mathrm{MPa}$ (50 psia). (b) Zone 11 (primary); combustor pressure, $0.69 \mathrm{MPa}$ (100 psia).

Figure 7. - Variation in spectral flame radiance with spectral wave Ingth; fuel air ratio, 0. 016; Jet $A$ and ERBS fuels; inlet air temperature, 533 K $1500^{\circ}+1$; fuel nozzle, AN 12.

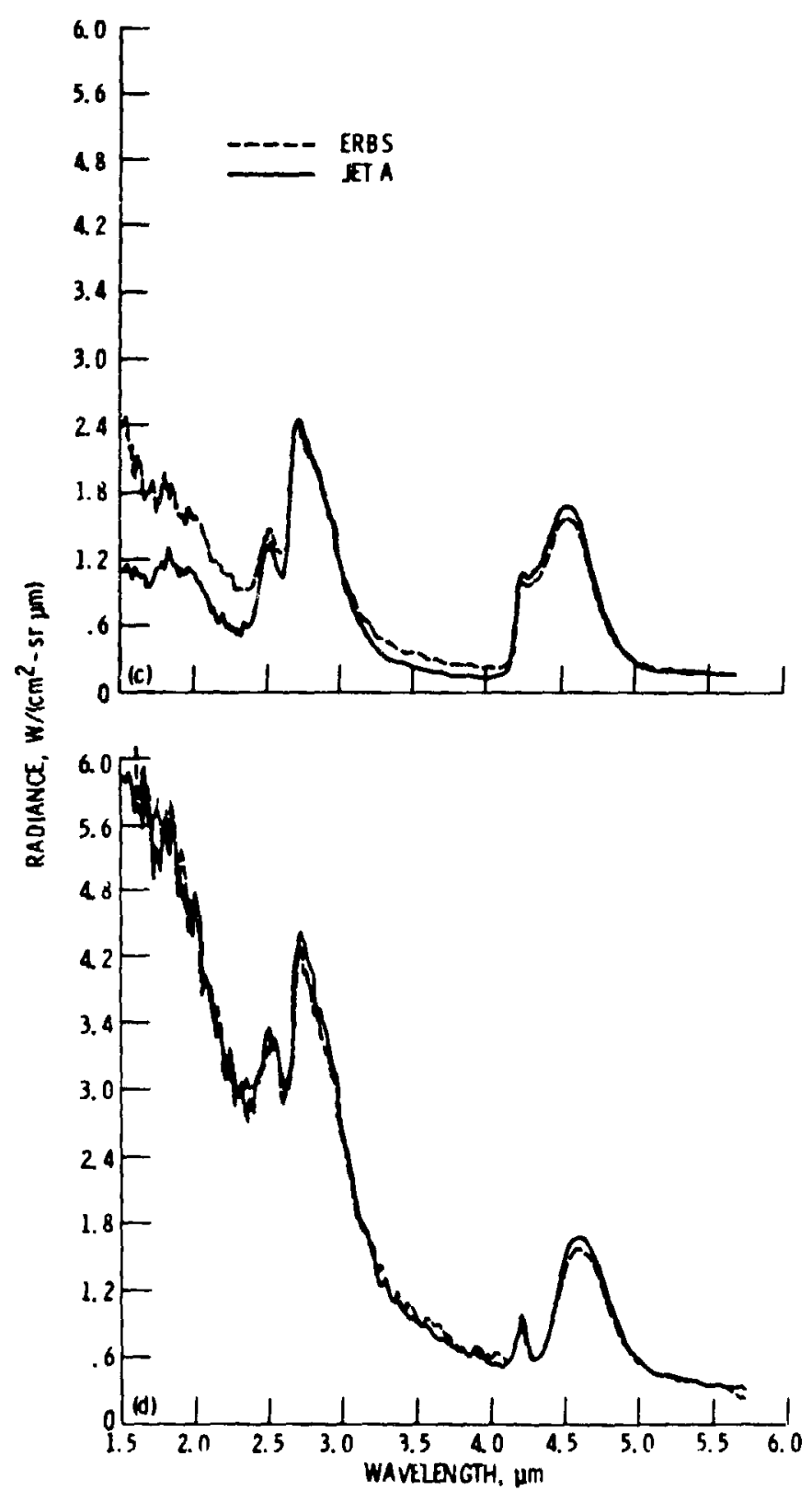

(c) Zone I - (secondary); combustor pressure, Q.34 MPa $(50$ psia). (d) Zone 2 (secondary); combustor pressure, $0.69 \mathrm{MPa}(100 \mathrm{psia}$ ).

figure 7. - continued. 


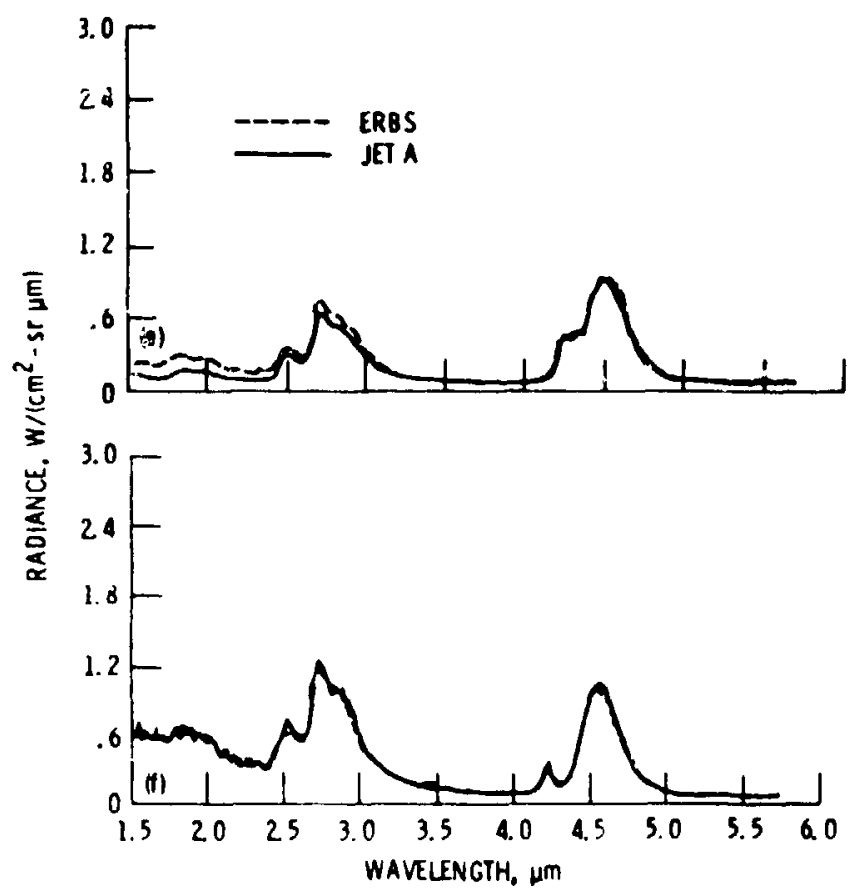

(e) Zone 3 (tertiary); combustor pressure, a $34 \mathrm{MPa}$ (50 psia). (f) Zone 3 (tertiary): combustor pressure, Q.69 MPa $(100$ psia). Figure 7. - Concluded.

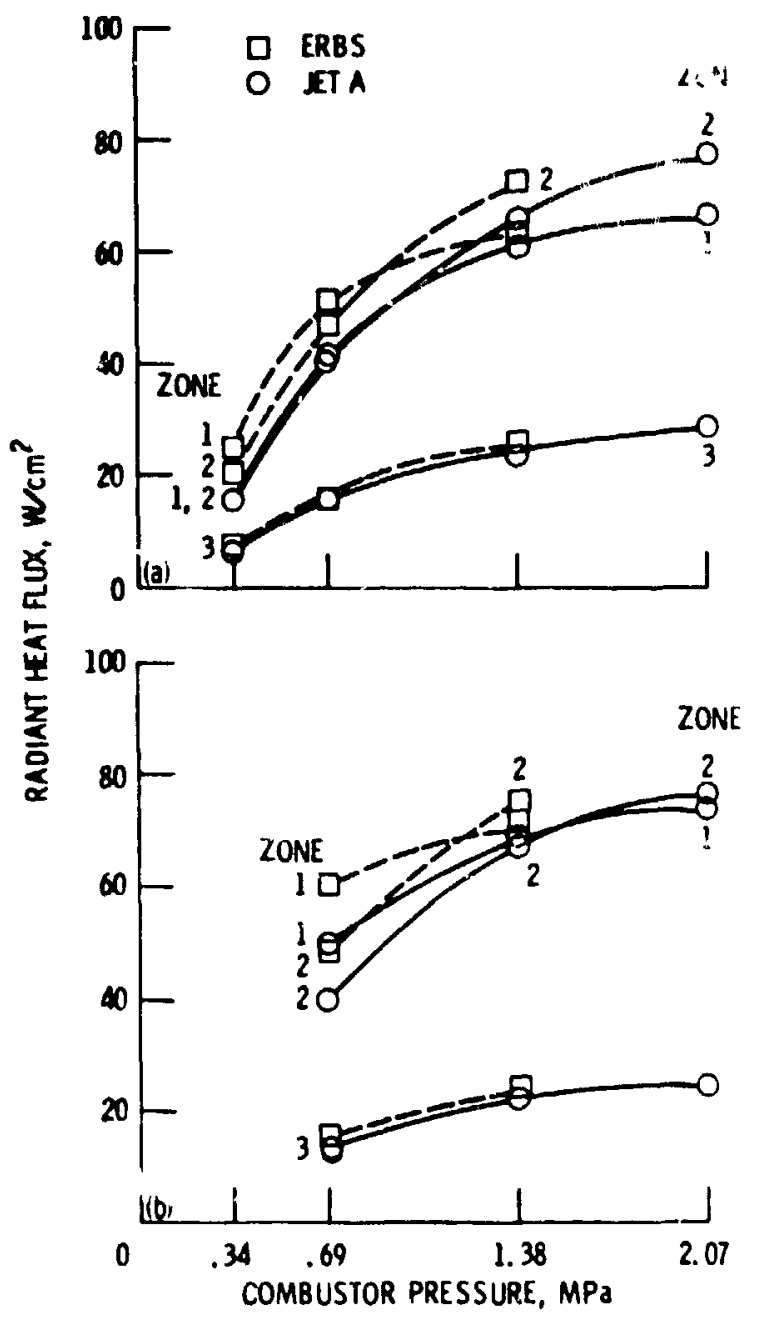

(a) Inlet air temperature, $533 \mathrm{~K}\left(500^{\circ} \mathrm{F}\right)$. (b) Inlet air temperature, $616 \mathrm{~K}\left(650^{\circ} \mathrm{F}\right)$.

Figure 8. - Variotion in total radiant heat flux by combustion zone with increase in combustor pressure; fuel-air ratio, 0.016; Jet $A$ and ERBS fueis; fuel nozale, FN 12. 


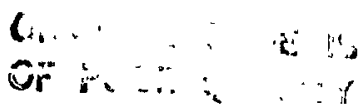
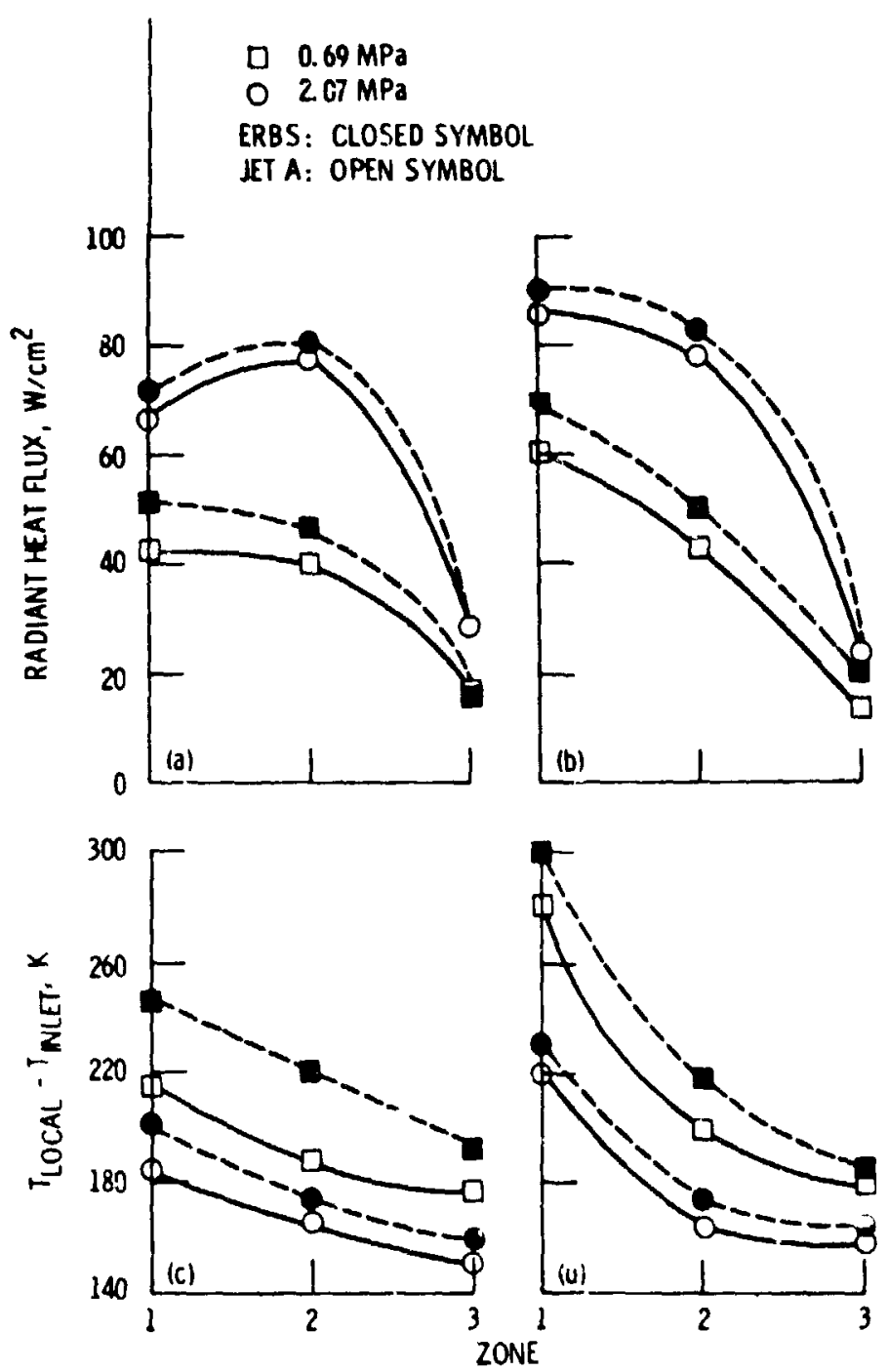

(a) Inlet air temperature, $5^{n n} \mathrm{~K}\left(500^{\circ} \mathrm{F}\right)$. (b) inlet air temperature, $700 \mathrm{~K}\left(800^{\circ} \mathrm{F}\right)$. (c) Inlet air temperature, $533 \mathrm{~K}\left(500^{\circ} \mathrm{F}\right)$. (d) Inlet air temperature, $700 \mathrm{~K}\left(800^{\circ} \mathrm{F}\right)$.

Figure 9. - Comparison ur radiant heat flux variation and liner temperature variation by combustion zone: fuel-air ratio, 0.016; Jet A and ERBS fuels; combustor pressures, $0.59 \mathrm{MPa}(100 \mathrm{psia}$ ) and $2.07 \mathrm{MPa}$ (300 psia): fuel nozzle, FN 12. 